\title{
JUMLAH KOLONI BAKTERI PADA TELAPAK TANGAN PERAWAT YANG MELAKUKANTINDAKAN MEDIS MENGGUNAKAN HANDSCOON
}

\author{
Dyah Widodo, Susi Milwati, Diah Rika Qurotul A.T, \\ Poltekkes Kemenkes Malang, Jalan Besar Ijen No 77 C Malang \\ Email: dyah_widodo@yahoo.com

\section{Total Of Bacteria Colonies On Hand Care Who Do Medical Action Using Handscoon}

\begin{abstract}
Hand washing is a thing that must do by medicals team before and after taking action to patiens. Hand hygiene can avoid transmissions of microorganism and can decrease the nosokomial infection that occurred. Caused the number of nosocomial infection is increasing, we need a way which can decrease it's number with washing hand in case nurse after taking action to the patient with handscoon. This research use pre eksperimental design, It begin with microbiology swab on the palm hand of nurse after they taking action to patiens with handscoon after and before they hand hygiene. Subject in this research is 10 sample with purposive sampling. The result of this research show that there are not defference number of the bacterial colonies in the palms of nurse between before and after hand washing with before is 35,9 CFU/ml and after hand washing is 55,2 CFU/ml, both of the number show that this is pathogen. This result support that how important a perfect handscoon for the medical action.
\end{abstract}

Keywords: number of bacterial colonies, hand hygiene.

\begin{abstract}
Abstrak: Tujuan penelitian ini adalah untuk mengetahui perbedaan jumlah koloni bakteri pada telapak tangan perawat sebelum dan sesudah melakukan cuci tangan medis setelah perawat melakukan tindakan keperawatan dengan menggunakan handscoon. Desain penelitian ini adalah Pre Eksperimental yang dilakukan dengan cara melakukan swab pada telapak tangan perawat yang setelah melakukan tindakan dengan menggunakan handscoon. Subjek penelitian berjumlah 10 sampel di ruang Bougenvil dengan teknik purposive sampling. Hasil penelitian ini menunjukkan bahwa tidak ada perbedaan jumlah koloni bakteri pada telapak tangan perawat yang cuci tangan sebelum dan sesudah setelah melakukan tindakan dengan menggunakan handscoon, dimana jumlah koloni sebelum cuci tangan 35,9 CFU/ml dinyatakan pathogen serta jumlah koloni bakteri setelah cuci tangan 55,2 CFU/ml dinyatakan pathogen juga. Hal ini mendukung bahwa pentingnya pemakaian handscoon yang utuh saat melakukan tindakan medis.
\end{abstract}

Kata Kunci: jumlah koloni bakteri, cuci tangan

\section{PENDAHULUAN}

Dalamaktivitas sehari-hari tangan seringkali terkontaminasi dengan mikroba, sehingga tangan dapat menjadi perantara masuknya mikroba ke dalam tubuh. Salah satu cara yang paling sederhana dan paling umum dilakukan untuk menjaga kebersihan tangan adalah dengan mencuci tangan menggunakan sabun. Mencuci tangan memegang peranan yang sangat penting terhadap penularan infeksi baik dari perawat ke pasien diruang rawat inap atau bahkan penularan infeksi diruangan bedah pada saat dilakukan pembedahan. Menjaga kebersihan tangan dengan baik dapat mencegah penularan mikroorganisme dan menurunkan frekuensi infeksi nosokomial (Depkes, 2009). Menurut penelitian Loho dan Utami (2007), salah satu metode penyebaran infeksi terpenting pada sarana kesehatan adalah melalui tangan petugas kesehatan. Organisme patogen dari pasien yang terinfeksi atau dari lingkungan mengkontaminasi tangan petugas kesehatan selama aktivitas klinik kemudian tersebar ke pasien lain. Tiga dari Jumlah total bakteri yang terdapat pada tangan tenaga medis bervariasi antara 3,9x10a hingga 4,6x106. Jumlah ini meningkat seiring bertambahnya durasi 
aktivitas klinik. Berdasarkan data dari WHO tahun 2013 secara global 10\% pasien rawat inap menderita infeksi nosokomial dari rumah sakit dan 1,4 juta kematian setiap hari diseluruh dunia, di Indonesia angka HAI (Hospital Acquired Infection) mencapai 9,8\%. Selain itu, penelitian dari Institute of Medcine AS menyebutkan bahwa di tahun 2008 sekitar 98.000 pasien meninggal karena infeksi nosokomial, diperkirakan di negara berkembang bisa mencapai $2 x$ lipatnya dan kepatuhan tenaga medis dalam mencuci tangan sebesar 40-50\% di rumah sakit. Pada tahun 2012 di RS George Elliot, Inggris 3 dari 5 bayi lahir prematur di ruang NICU terinfeksi bakteri Serratia marcescens yang akhirnya merenggut nyawanya setelah dirawat selama seminggu, setelah dilakukan pemeriksaan pada seluruh tim medis di ruang NICU lebih dari $50 \%$ ditemukan bakteri tersebut ditangan tim medis di ruang NICU.

Penelitian dari WHO terbaru tahun 2013 menyatakan bahwa mencuci tangan bisa mencegah dan menghilangkan $92 \%$ organisme penyebab infeksi di tangan. Menurut penelitian Triatmodjo (1993), menemukan bahwa 34,4\% tangan perawat terkontaminasi oleh kuman penyebab infeksi nosokomial dan 34,4\% dari alat-alat bedah steril siap pakai ternyata dalam kondisi tidak steril.

Berbagai macam kasus infeksi di rumah sakit setiap tahunnya terjadi peningkatan, hasil survei dari 11 Rumah Sakit di Jakarta yang dilakukan oleh Perdalin Jaya di Rumah Sakit penyakit infeksi Prof. Dr. Sulianti Saroso Jakarta (2003) didapatkan angka infeksi nosokomial untuk ILO (Infeksi Luka Operasi) 18,9\%, ISK (Infeksi Saluran Kemih) 15,1\%, IADP (Infeksi Aliran Darah Primer) 26,4\%, Pneumonia 24,5\% dan Infeksi Saluran Napas lain 15,1\%, serta Infeksi lain 32,1\% (Depkes RI, 2012). Adanya koloni bakteri ditangan perawat maupun diruangan akan meningkatkan resiko infeksi. Berdasarkan penelitian dari Valerie Curtis pada tahun 2009 dari London school of hygiene and tropical kebiasaan mencuci tangan bisa menekan angka kejadian diare sebesar $47 \%$, data riset dari UNICEF pada tahun 2012 menyatakan bahwa Indonesia merupakan satu dari 15 negara dengan jumlah tertinggi kematian anak dengan diare dan infeksi saluran pernafasan, yaitu 29.000 kasus pertahun

Tujuan penelitian ini untuk mengetahui perbedaan jumlah koloni bakteri pada telapak tangan perawat yang cuci tangan sebelum dan sesudah melakukan tindakan medis dengan menggunakan handscoon di ruang Bougenvile Rumah sakit Ngudi Waluyo Wlingi Blitar.

\section{METODE PENELITIAN}

Dalam penelitian ini, peneliti menggunakan penelitian Pre eksperimental dengan one group pre-post test design yang berarti suatu rancangan penelitian yang tidak menggunakan kelompok kontrol akan tetapi sudah dilakukan observasi pertama (pre test) yang memungkinkan menguji perubahan-perubahan yang terjadi setelah adanya intervensi (post test) (Notoadmodjo, 2010). Penelitian ini dilakukan dengan cara melakukan intervensi pada responden berupa cuci tangan medis kepada perawat sesuai dengan SOP di rumah sakit tersebut kemudian pengukuran dilakukan sebanyak $2 x$ yaitu sebelum melakukan cuci tangan medis dan setelah melakukan cuci tangan medis setelah 40 detik. Jumlah populasi didalampenelitian ini sejumlah 24 orang perawat di ruang rawat inap bedah RSUD Ngudi Waluyo Wlingi Blitar. Sampel yang digunakan dalam penelitian ini sebanyak 10 Orang atau $50 \%$ dari total populasi perawat ruang rawat inap bedah di RSUD Ngudi Waluyo Wlingi Blitar. Metode pengambilan sampel yang digunakan adalah purposive sampling, artinya sampel yang digunakan adalah sesuai dengan tujuan dari penelitian. 
Penelitian dilakukan pada tanggal 31 Mei 2017 bertempat di Ruang Bougenvil Rumah Sakit Umum Daerah Ngudi Waluyo Wlingi Blitar. Metode pengumpulan data adalah menggunakan lembar observasi cuci tangan, lembar hasil laboratorium dan pedoman waawancara yang berisi tentang data umum responden seperti umur, jenis kelamin, lama bekerja dan jenjang pendidikan.

Pengolahan data dalam penelitian ini menggunakan coding pada setiap variabel dan menggunakan scoring yang pada akhirnya ditemukan adanya perbedaan jumlah koloni bakteri pada telapak tangan perawat. Analisa data menggunakan analisa deskriptif yang mana akan disajikan dengan distribusi frekuensi dalam bentuk diagram, tabel mapun narasi untuk mempermudah pembaca dengan acuan sebagai berikut : Total Plate Count dinyatakan pathogen apabila hasil TPC $>5-10 \mathrm{CFU} / \mathrm{mL}$ dan masih bisa ditolerir jika hasilnya $<5-10 \mathrm{CFU} / \mathrm{ml}$, Total Coliformakan dinyatakan pathogen jika hasilnya $>3 \times 10^{2} \mathrm{MPN} / \mathrm{mL}$ dan dapat ditoleris jika $<$ dari
$3 \times 10^{2} \mathrm{MPN} / \mathrm{mL}$ dan Kuman E.coli akan dinyatakan dengan tanda (+) jika terdapat ditelapak tangan dan dinyatakan (-) jika tidak ada. Penelitian ini mengunakan taraf signifikasi $\alpha=0,05$ dan derajat kepercayaan sebesar 95\%. Kriteria pengambilan keputusan data sebagai berikut: Ha diterima jika nilai $p$ value $\leq 0,05$ yang berarti ada perbedaan jumlah koloni bakteri sebelum dan sesudah cuci tangan medis. Ha ditolak jika nilai $p$ value $\geq 0,05$ yang berarti tidak ada perbedaan jumlah koloni bakteri sebelum dan sesudah cuci tangan medis.

\section{HASIL PENELITIAN}

Berdasarkan Tabel 1, dapat diketahui bahwa rata- rata pelaksanaan cuci tangan medis oleh perawat jaga di Ruang Bougenvil RSUD Ngudi Waluyo Wlingi Blitar sesuai dengan SOP sebanyak $93 \%$ dengan keterangan 5 sampel melakukan cuci tangan secara lengkap 6 langkah cuci tangan dan 5 sampel melakukan cuci tangan dengan tidak lengkap dimana sebagian besar kesalahan terletak pada tidak dilepasnya

Tabel 1. Hasil Observasi Pelaksanaan Cuci Tangan Medis Sebelum swab Telapak Tangan

\begin{tabular}{ccc}
\hline Sampel & $\begin{array}{c}\text { Kelengkapan L angksh } \\
\text { Cuci Tangan }\end{array}$ & $\%$ \\
\hline CT 1 & Tidak Lengkap & 90 \\
CT 2 & Tidak Lengkap & 80 \\
CT 3 & Lengkap & 100 \\
CT 4 & Tidak Lengkap & 90 \\
CT 5 & Tidak Lengkap & 80 \\
CT 6 & Lengkap & 100 \\
CT 7 & Lengkap & 100 \\
CT 8 & Tidak Lengkap & 90 \\
CT 9 & Lengkap & 100 \\
CT 10 & Lengkap & 100 \\
\hline Rata-rata & 93\% \\
\hline
\end{tabular}


perhiasan atau jam tangan yang ada pada tangan perawat sebelum ataupun sesudah cuci tangan.

Untuk hasil pemeriksaan TPC (Total Plate Count) didapatkan hasil bahwa jumlah koloni bakteri yang ditemukan pada telapak tangan perawat diruang Bougenvil bervariasi dengan hasil 8 telapak tangan perawat terkontaminasi bakteri pathogen sebelum melakukan cuci tangan, 2 orang lainnya mendapatkan hasil tidak terkontaminasi bakteri pathogen, sedangkan setelah melakukan cuci tangan diketahui bahwa 6 telapak tangan perawat terkontaminasi oleh bakteri pathogen dan 4 lainnya tidak terkontaminasi oleh bakteripathogen. Dari hasil tersebut dapat diketahui bahwa 7 sampel mengalami penurunan jumlah koloni bakteri dan 3 lainnya mengalami kenaikan yang signifikan dari angka sebelum cuci tangan dengan angka setelah cuci tangan. Sehingga dapat disimpulkan bahwa tidak semua data hasil pemeriksaan jumlah koloni bakteri mengalami penurunan setelah dilakukan cuci tangan medis pada perawat setelah melakukan tindakan keperawatan di ruang Bougenvil RSUD Ngudi Waluyo Wlingi Blitar.

Pada hasil pemeriksaaan jumlah koloni coliform, pada kondisi sebelum cuci tangan dari 10 sampel seluruhnya mendapat angka normal yaitu $<3 \times 10^{2} \mathrm{MPN} / \mathrm{mL}$ yang artinya tidak terdapat bakteri coliform yang patogen ditelapak tangan perawat. Sedangkan pada kondisi setelah cuci tangan 9 orang mendapatkan angka normal dan 1 orang mendapatkan angka $4 \times 10^{2} \mathrm{MPN} /$ $\mathrm{mL}$ yang artinya ada bakteri patogen yang hidup pada telapak tangan perawat. Pada pemeriksaaan E.coli didapatkan hasil sebelum dan sesudah cuci tangan mendapatkan hasil negative yang artinya tidak ada bakteri E.coli yang hidup pada telapak tangan perawat.

Berdasarkan hasil analisis uji statistik normalitas data menggunakan Kolmogrov Smirnov didapatkan data nilai pre dan post jumlah koloni bakteri berdistribusi tidak normal yaitu 0,024 dan 0,000 , sehingga kemudian kedua data dilakukan uji beda Wilcoxon di dapat hasil $p$ value sebesar 0,203>0,05. Sehingga dapat diartikan bahwa $\mathrm{HO}$ diterima yang artinya tidak ada perbedaan yang bermakna antara jumlah koloni bakteri pada telapak tangan perawat yang telah melakukan tindakan keperawatan dengan memakai handscoon pada saat sebelum dan sesudah dilakukan cuci tangan medis diruang Bougenvil RSUD Ngudi Waluyo Wlingi Blitar.

\section{PEMBAHASAN}

Hasil observasi yang dilakukan oleh peneliti didapatkan bahwa 5 perawat melakukan langkah- langkah cuci tangan dengan lengkap dan 5 orang lainnya melakukan cuci tangan dengan langkah yang tidak lengkap dengan rata-rata persentase cuci tangan sesuai SOP sebesar 93\% dari total capaian $100 \%$, sedangkan $7 \%$ data ketidaklengkapan langkah-langkah dalam pelaksanaan cuci tangan terjadi dikarenakan sebagian besar perawat mengenakan perhiasan ditangan baik jam tangan ataupun gelang dan cincin yang tidak dilepas ketika melakukan cuci tangan, sebagian lagi dikarenakan lupa dengan langkah-langkah yang harus dilakukan secara berurutan. Menurut WHO kepatuhan adalah hal yang harus dimiliki oleh perawat. Kepatuhan perawat dalam melakukan cuci tangan bisa ditunjukkan melalui kelengkapan langkahlangkah yang dilakukan dalam cuci tangan harus lebih dari $80 \%$.

Hal ini tentu akan mempengaruhi hasil jumlah koloni bakteri pada telapak tangan, karena logam merupakan suatu benda/tempat yang memungkinkan adanya koloni bakteri yang menempel dan tertinggal disela-sela cincin/ ogam meskipun sudah melakukan cuci tangan. Teori tersebut didukung dengan penelitian yang dilakukan oleh Noah Fierer pada tahun 2008 mengatakan bahwa jumlah koloni bakteri pada pada selasela benda yang menempel ditangan sebesar 223 $\mathrm{CFU} / \mathrm{m}^{2}$ pada benda logam maupun non logam. 
Pada ruang Bougenvile ada 5 orang melakukan cuci tangan secara tidak sempurna atau tidak sesuai dengan prosedur, hal ini disebabkan karena banyaknya pekerjaan yang harus dilakukan baik untuk merawat pasien ataupun melakukan dokumentasi asuhan keperawatan sehingga tidak bisa berlama- lama untuk cuci tangan. Berdasarkan hasil observasi 5 orang ini 4 diantaranya telah berusia diatas 45 tahun, sehingga meskipun pada saat diskusi mampu melakukan secara urut akan tetapi pada saat pelaksanaan masih ada langkah yang terlewat.

Dalam penelitian ini, perawat ruang Bougenvil RSUD Ngudi Waluyo Wlingi Blitar melakukan cuci tangan sesuai prosedural dengan capaian $93 \%$ yang artinya secara keseluruhan perilaku perawat ruang Bougenvil RSUD Ngudi Waluyo Wlingi Blitar dalam menjalankan langkahlangkah cuci tangan sudah baik akan tetapi perlu untuk dilakukan monitoring dan evaluasi pelaksanaanya secara individu.

Hasil dari pemeriksaaan jumlah koloni bakteri colliform sebelum cuci tangan dalam penelitian ini dari 10 sampel didapatkan hasil $3 \times 10^{2} \mathrm{MPN} / \mathrm{ml}$ yang artinya pada kondisi sebelum mencuci tangan kondisi tangan pada sampel ini bebas dari bakteri patogen. Hasil penelitian ini sejalan dengan penelitian yang dilakukan oleh Kemenkes (2012) bahwa mengacu pada SNI (Standart Nasional Indonesia) Laboratorium No 01-2897-1992 bahwa bakteri indikator cemaran haruslah dinyatakan negative atau kurang dari $3 \times 10^{2} \mathrm{MPN} / \mathrm{ml}$ dalam semua jenis pemeriksaan lingkungan. Penelitian ini juga sejalan dengan Susiati (2008) bahwa tujuan cuci tangan adalah untuk menghilangkan bakteri dan kotoran yang menempel pada tangan. Sedangkan, pada hasil setelah cuci tangan justru didapatkan hasil 9 orang mendapatkan hasil $3 \times 10^{2} \mathrm{MPN} / \mathrm{ml}$ yang artinya normal dan bebas bakteri pathogen, sedangkan 1 sampel dengan nilai diatas normal, yaitu $4 \times 10^{2} \mathrm{MPN} / \mathrm{ml}$ yang artinya ada bakteri coliform pada telapak tangan ini yang berpotensi pathogen terhadap kesehatan. Hasil dari penelitian ini berbeda dengan pemeriksaan mikrobiologi pada lingkungan dengan nilai normal yang mengacu pada SNI (Standart Nasional Indonesia) Laboratorium No 01-2897-1992 menyatakan bahwa total colliform dinyatakan tidak patogen jika nilainya $<3 \times 10^{2} \mathrm{MPN} / \mathrm{ml}$.

Penelitian ini sejalan dengan teori yang dinyatakan oleh Jawetz et al (2008) bahwa bakteri coliform merupakan suatu bakteri yang dijadikan indikator cemaran dalam lingkungan yang mengindikasikan adanya bakteri patogen didalam telapak tangan atau lingkungan yang lain karena mempunyai kemampuan bertahan hidup lebih lama dengan suhu kamar dibandingkan jenis bakteri, virus atau parasit yang lainnya, selain itu bakteri coliform juga berkemampuan sangat mudah untuk berkembang biak pada lingkungan baru. Beberapa contoh bakteri coliform yang memungkinkan terdapat atau mampu bertahan hidup di telapak tangan adalah Enterobacter aerogenes, Klebsiella, Citrobacter, Streptococcus dan Escherechia coli yang mana penyebarannya melalui aerob, anaerob dan secara fecal oral.

Dari hasil penelitian ini dapat diketahui bahwa meskipun telah mencuci tangan dengan langkah yang benar bakteri coliform yang berasal dari lingkungan luar dapat menempel pada telapak tangan dan mampu bertahan hidup pada telapak tangan serta dapat berkembang biak.

Observasi cuci tangan ini dilakukan setelah perawat melakukan aktivitas perawatan dengan menggunakan sarung tangan dirawat inap seperti merawat setiap jenis luka, setelah tindakan invasive tertentu sepertimemasang kateter, memasang infuse, memasang ngt, tentunya meskipun memakai sarung tangan bersih maupun steril, tidak menutup kemungkinan tangan diduga tercemar dengan mikroorganisme khususnya pada tindakan yang memungkinkan kontak 
dengan darah, selaput lendir, cairan tubuh, sekresi atau ekresi, Setelah menyentuh benda yang kemungkinan terkontaminasi dengan mikroorganisme virulen atau secara epidemiologis merupakan mikroorganisme penting.

Hasil dari penelitian dengan analisis uji statistik yaitu uji beda Willcoxon didapatkan hasil $\mathrm{p}$ value sebesar 0,203 . Sehingga dapat di artikan bahwa $\mathrm{H0}$ diterima yang artinya tidak ada perbedaan yang bermakna antara jumlah koloni bakteri pada telapak tangan perawat sebelum dan sesudah dilakukan cuci tangan medis diruang Bougenvil RSUD Ngudi Waluyo Wlingi Blitar sehingga bisa diartikan tidak adanya perubahan jumlah koloni bakteri yang signifikan setelah kita mencucitangan.

Penelitian ini mempunyai hasil yang berbeda dengan penelitian WHO terbaru tahun 2013 menyatakan bahwa mencuci tangan bisa mencegah dan menghilangkan $92 \%$ organisme penyebab infeksi nosokomial di tangan, sedangkan hasil yang didapatkan oleh peneliti dalam penelitian ini adalah jumlah koloni bakteri dengan menggunakan TPC (Total Plate Count) sebelum melakukan cuci tangan sebesar 35,9 $\mathrm{CFU} / \mathrm{ml}$ dan hasil koloni bakteri sesudah melakukan cuci tangan sebesar 55,2 CFU/ml yang artinya kedua nilai ini melebihi nilai normal yaitu 0-5 CFU/ml sehingga dapat dikatakan koloni bakteri ini berpotensi pathogen terhadap manusia. Dilakukannya cuci tangan secara prosedural didalam penelitian ini tidak mempengaruhi terjadinya penurunan mikroorganisme yang ada pada telapak tangan, akan tetapi justru mengalami kenaikan jumlah koloni bakteri sebesar 19,3 CFU/ml yang artinya meskipun melakukan cuci tangan nilai koloni bakteri meningkat dari kondisi sebelum dan sesudah melakukan cuci tangan.

Penelitian ini sejalan dengan penelitian yang dilakukan oleh Triatmodjo (1993), menemukan bahwa $34,4 \%$ tangan perawat terkontaminasi oleh kuman penyebab infeksi nosokomial meskipun sudah dilakukan cuci tangan dan $34,4 \%$ dari alat-alat bedah steril siap pakai ternyata dalam kondisi tidak steril. Penelitian ini sependapat dengan penelitian yang dilakukan oleh Triatmodjo (1993) bahwa ada banyak faktor yang mempengaruhi baik dalam proses cuci tangan, bahan dan alat yang digunakan untuk cuci tangan ataupun jenis koloni bakteri itu sendiri. Jika dilihat dari sisi bahan dan alat yang digunakan untuk mencuci tangan, ruang rawat inap Bougenvil menggunakan sabun cair dimana dalam kandungannya terdapat biodegradable surfaktan dan emollient yang berfungsi hanya untuk melepaskan kotoran melalui media air dan tidak terdapat antiseptik jenis apapun didalamnya. Sehingga tidak menutup kemungkinan masih banyak bakteri yang tertinggal pada telapak tangan karena sabun yang digunakan tidak mempunyai kemampuan yang bakterisidal yaitu kemampuan untuk membunuh bakteri dengan baik.

Penelitian dari Loho dan Utami (2007) menyebutkan bahwa membersihkan tangan dengan bahan antiseptik mulai dikenal sejak awal abad 19 Ignaz Semmelweis pada tahun 1847 memerintahkan setiap dokter dan mahasiswa kedokteran mencuci tangan dengan larutan hipoklorit setiap kali akan menangani seorang pasien. Tindakan initerbukti menurunkan angka kematian ibu. Sejak saat itu telah banyak dilakukan penelitian yang membuktikan bahwa tindakan mencuci tangan yang dilakukan oleh tenaga kesehatan dengan menggunakan bahan antiseptik dapat menurunkan secara bermakna penyebaran kuman patogen melalui tangan petugas kesehatan dan kejadian infeksi nosokomial.

Proses cuci tangan yang dilakukan oleh perawat di ruang Bougenvil sebenarnya sudah sesuai dengan SOP yang ada, akan tetapi sebagian besar dari perawat banyak yang tidak melepaskan perhiasan yang menempel pada jari tangan, seperti cincin. Pada langkah-langkah cuci 
tangan medis menurut WHO tahun 2009 telah dianjurkan untuk melepaskan perhiasan sebelum cuci tangan dikarenakan dengan melepaskan seluruh perhiasan yang menempel pada area telapak tangan, maka kemungkinan bakteriuntuk tinggal menetap akan semakin kecil, sehingga kemungkinan adanya infeksi silang akan semakin kecil. Selain dari poin tersebut, sebagian perawat diruang Bougenvil menutup kran air menggunakan jari- jari tangan, sedangkan idealnya menggunakan siku, hal ini juga memungkinkan adanya kontaminasi bakteri yang ada di kran air menempel pada telapak tangan perawat.

Adapun jenis air yang digunakan juga dapat mempengaruhi bertambahnya jumlah koloni bakteri pada telapak tangan setelah melakukan cuci tangan, perbedaan penggunaan air PDAM dan air sumur tentunya ada perbedaan dari jumlah bakteri yang terkandung didalamnya, hal ini tidak menutup kemungkinan akan berkontribusi dalam mengkontaminasi telapak tangan setelah melakukan cuci tangan meskipun menggunakan sabun. Penelitian yang sejalan dengan penelitian ini adalah penelitian Kemenkes RI tahun 2011 tentang uji mikrobiologi air membuktikan bahwa pada air sumur terdapat jumlah koloni bakteri coliform sebesar 1.100 MPN/100 ml air dan pada air PDAM sebesar 210 MPN/100ml air, hal ini menunjukkan bahwa terdapat bakteri coliform yang patogen didalam air, dengan kondisi inilah tidak menutup kemungkinan setelah perawat melakukan cucitangan, tangan perawat justru akan terkontaminasi dengan bakteri lain yang berasal dari air yang digunakan oleh rumah sakit tersebut, seperti dalam penelitian ini hasil swab telapak tangan dengan nilai jumlah koloni meningkat dari kondisi sebelum cuci tangan ke kondisi setelah cuci tangan diduga terkontaminasi oleh bakteri dari luar.

Selain dari segi bahan dan proses atau cara cuci tangan, jumlah koloni bakteri dapat berkurang atau bertambah bergantung pada jenis bakteri dan kemampuan bakteri itu sendiri untuk bertahan hidup lebih lama pada telapak tangan manusia. Menurut Cooke et al., (2000) bakteri melekat pada tubuh inang dengan menggunakan phili. Phili yang berada dipermukaan memungkinkan bakteri melekat pada sel epitel atau mukosa. Pada bakteri Gram Negatif, adanya suatu kapsul mukosa protektif yang mengelilingi dinding sel memperkecil resiko desikasi, sehingga bakteri ini dapat bertahan hidup lebih lama ditangan dan lebih besar kemungkinannya menimbulkan infeksi silang, peneliti sependapat dengan teori ini bahwa tidak semua bakteri bisa hilang dari permukaan tubuh manusia hanya dengan air dan sabun yang tidak mempunyai kemampuan bakterisidal, bakteri jenis Gram Negatif mampu hidup lebih lama dalam permukaan tubuh manusia dan kemungkinan masih tertinggal dan hidup berkembang biak dibagian tubuh tersebut sangat besar.

Bakteri flora normal juga dapat berperan besar terhadap kenaikan angka koloni bakteri ini, dikarenakan setiap permukaan tubuh kita adalah tempat bagi kehidupan bakteri dari jenis yang berbeda-beda dan mempunyai karakteristik yang berbeda-beda pula. Menurut Jawetz et al (2004), bakteri dapat hidup dan berkembang biak pada bagian tubuh tertentu berdasarkan faktor nutrisi, kelembapan serta suhu dan kebutuhan air. Flora normal akan hidup dan tidak menimbulkan patogen apabila dalam jumlah yang normal, apabila jumlah flora normal dalam kulit kita tumbuh diatas normal, jika terjadi supresi flora normal akan menimbulkan tempat kosong yang cenderung akan diisi oleh mikroorganisme dari lingkungan atau tempat lain pada tubuh dan beberapa organisme bersifat oportunis dan bisa menjadi patogen.

Berdasarkan data hasil uji TPC dan Total Coliform pada 10 orang sampel perawat dinyatakan bahwa terjadi penurunan jumlah koloni bakteri sebelum ke sesudah cuci tangan sejumlah 7 sampel dan ada kenaikan yang cukup signifikan dari sebelum ke setelah cuci tangan 
sejumlah 3 sampel. Dari hasil analisis uji statistik didapatkan hasil bahwa p value sebesar 0,203 yang artinya $\mathrm{HO}$ diterima sehingga tidak ada perbedaan yang signifikan pada jumlah koloni bakteri pada telapak tangan perawat yang cuci tangan sebelum dan sesudah melakukan tindakan medis diruang Bougenvil RSUD Ngudi Waluyo Wlingi Blitar.

Penggunaan alat pelindung diri, terutama sarung tangan yang digunakan oleh tim medis dalam melakukan perawatan kepada pasien dapat mengurangi menyebarnya infeksi nosokomial yang dapat dibawa oleh petugas dari pasien yang satu ke pasien yang lainnya. Peneliti sejalan dengan penelitian yang dilakukan oleh Ambarwati (2009) menyatakan bahwa dengan memakai APD baik itu handscoon, scort, topi dan masker dapat melindungi tenaga medis dari paparan atau kontaminasi bakteri dan mencegah penyebaran nosokomial dari pasien satu dengan pasien yang lain. Bahan handscoon yang digunakan juga akan membantu dalam mencegah terjadinya kontaminasi atau perpindahan mikroorganisme pada telapak tangan, ada beberapa bahan yang biasanya digunakan untuk pembuatan handscoon adalah vinyl, latex dan nitrile. Bahan yang paling bagus digunakan adalah bahan latex atau nitrile karena berasal dari karet alam dan elastis serta tidak mudah sobek dan lebih tahan dari benda tajam.

Dari hasil penelitian ini menunjukkan bahwa tidak ada perbedaan pada jumlah koloni bakteri sebelum dan sesudah ketika kita melakukan cuci tangan dengan cara yang tidak tepat dan tidak menggunakan sabun dengan antiseptik yang mempunyai kemampuan untuk membunuh bakteri. Sehingga penelitian ini juga sependapat bahwa pentingnya tenaga medis menggunakan sarung tangan sebelum melakukan tindakan medis bagi terutama perawat diruangan baik tindakan invasif ataupun tidak, baik menggunakan sarung tangan steril maupun tidak. Akan tetapi, tidak hanya perawat saja seluruh tim medis ataupun non medis dianjurkan untuk menggunakan sarung tangan untuk mencegah kontaminasi bakteri dari tangan petugas ke pasien maupun pada diri petugas sendiri dan mengurangi persebaran infeksi nosokomial yang berasal dari petugas medis. Sehingga seluruh tim medis maupun non medis dapat berperan membantu mengurangi angka kejadian infeksi nosokomial yang terjadi di rumah sakit.

\section{PENUTUP}

Jumlah koloni coliform dan E.coli dinyatakan negatif pada telapak tangan perawat, akan tetapi jumlah koloni sebelum cuci tangan dan sesudah cuci tangan tidak mengalami penurunan yang signifikan sehingga didapatkan hasil bahwa tidak ada perbedaan yang signifikan antara jumlah koloni bakteri pada telapak tangan perawat setelah melakukan tindakan keperawatan dengan menggunakan handscoon pada saat sebelum dan sesudah dilakukan cuci tangan diruang Bougenvil RSUD Ngudi Waluyo Wlingi, Blitar sehingga penggunaan dan pemakaian handscoon yang utuh saat melakukan tindakan medis mampu melindungi tangan perawat dari bakteri yang ada pada telapak tangan perawat.

Dalam melakukan cuci tangan disarankan pada Rumah Sakit Ngudi Waluyo menggunakan sabun cair yang mengandung bahan antiseptic yang bakterisidal dan non iritatif pada kulit, dan tidak menimbulkan alergi. Sabun cuci tangan yang direkomendasikan WHO minimal mengandung senyawa golongan alcohol 50-80\%,triclosan, fenol, iodine atau golongan gluconate pada komposisi bahannya karena sudah di uji secara klinis bahwa senyawa tersebut diatas mampu mengurangi dan membunuh bakteri pada telapak tangan. Seluruh tim medis terutama perawat harus tetap menggunakan handscoon yang utuh baik steril maupun bersih sebagai APD saat melakukan tindakan medis baik invasive maupun non invasive diruangan, kondisikan handscoon dalam keadaan utuk tidak sobek dan digunakan 
secara disposable serta mematuhi dan menjalankan cuci tangan 6 langkah secara prosedural.

\section{DAFTAR PUSTAKA}

Ambarwati. (2009). Penelitian tentang : Hubungan Kepatuhan Penggunaan APD Terhadap Penurunan Jumlah Koloni Bakteri. Bandung

Angga. L, dkk. (2014). Penelitian tentang : Identifikasi Jenis Bakteri Kontaminan pada Telapak Tangan Perawat di Ruang Interna. Surabaya

Black et al. (2009). Manajemen Klinik pada Keperawatan Medikal Bedah ed. 7. Jakarta: EGC.

Caswell, P. (1997). Buku Ajar Medikal Bedah dan Manajemen di Ruang Pelayanan. Jakarta : Salemba Medika.

Cohen et al. (2006). Buku Ajar Mikrobiologi dan Parasitologi Kedokteran ed.8. Jakarta : EGC Kedokteran.

Cooke et al. (2000). Pathogenesis dan Infeksi Bakteri di Lingkungan serta Penatalaksanaanya. Jakarta: EGC.

Curtis, V. (2009). Penelitian tentang : Kebiasaan Mencuci Tangan dapat Menekan Angka Kejadian Penyakit. England: London school of hygiene and tropical.

Departemen Kesehatan Republik Indonesia. (2009). Tindakan General Precaution pada Tim Medis. Jakarta.

Fauzia. (2014). Penelitian tentang: Hubungan Jumlah Koloni Bakteri Setelah Cuci Tangan Terhadap Kepatuhan Perawat. Makassar

Gould, D. (2008). Mikrobiologi Terapan Untuk Perawat. Jakarta : EGC.

HPPI. (2010). Tentang Indikasi Cuci Tangan. Jakarta.

Jawetz et al. (2004). Medical Microbiology.
Jakarta : Salemba Medika.

Kenneth. (2012). Buku Ajar Ketrampilan Medikal Bedah. Jakarta : EGC.

Kemenkes RI. (2011). Penelitian tentang : Mikrobiologi Air PDAM dan Air Sumur. Jakarta

Kepmenkes RI no. 129. 2008. Standart Pelayanan Minimal Rumah Sakit. Jakarta.

Koes, I. (2006). Mikrobiologi Medis. Jakarta : EGC.

Larson. (2007). The Epidemiology and Parasitology clinic ed.5. Jakarta : EGC.

Loho, Utami. (2007). Penelitian Tentang Efektivitas Penggunaan Berbagai Macam Sabun Mandi terhadap Penurunan Jumlah Staphylococcus Aureus di Tangan Perawat. Yogyakarta : FIK Universitas Ahmad Dahlan.

Newson. (2005). Microbiology Clinical : General Precaution of Infection ed.5. Jakarta : EGC.

Noah Fierer. (2008). Research 2008 : Number of colony Microorganisms on Your Hands.

Perry and Potter. (1999). Fundamental Keperawatan : Cara Mencuci Tangan sesuai AORN (American Organisation Registered Nurse). Jakarta: EGC.

Purohito. (1995). Pengantar Tindakan Bedah Akut dan Dasar Ilmu Medikal Bedah. Surabaya : Airlangga Press.

Revans. (1986). Administrasi Pelayanan Kesehatan. Jakarta : EGC.

Riskesdas Kemenkes RI. Penelitian tentang : Pengaruh Kebiasaan Cuci Tangan terhadap Jumlah Angka Kejadian Infeksi Diare dan ISPA pada Anak. Jakarta.

Schaffer et al. (2010). Seri Pedoman Praktis: Pencegahan Infeksi dan Praktik yang Aman. Jakarta : EGC.

Susiati, M. 2008. Ketrampilan Dasar Keperawatan. Surabaya: Airlangga. 
Triatmodjo, 1993. Penelitian tentang : Gambaran Bakteriologis pada Tangan Perawat. Malang: Universitas Brawijaya.

UNICEF. 2012. Penelitian tentang : Angka Infeksi dan Kematian pada Anak.

WHO. 2009. Five Moment Hand Wash.

WHO. 2013. Penelitian Tentang : Jumlah Angka HAI di Global dan Indonesia. 